\title{
Effect of Synthetic Atrial Natriuretic Polypeptide on Hemorrhage-Induced Adrenocorticotropin Secretion of the Rat
}

\author{
Teruhiko HATTORI, Kozo HASHIMoto, Hiroshi INOUE, \\ MASANori SUGAWARA, SHuso SUEMARU, Jingo KAGEYAMA \\ AND ZENSUKE OTA
}

Third Department of Internal Medicine, Okayama University

Medical School, 2-5-1 Shikata-cho, Okayama 700

\begin{abstract}
The effect of synthetic alpha-human atrial natriuretic polypeptide ( $\alpha$-hANP) on the in vivo and in vitro release of ACTH and corticosterone was examined. In the in vivo study ACTH and corticosterone responses to rapid 2-ml/rat hemorrhage were measured in sixteen conscious rats after $\alpha$-hANP administration. The hemorrhage increased plasma ACTH and corticosterone concentrations in the control group of rats $(p>0.01)$. ANP inhibited hemorrhageinduced ACTH secretion $(\mathrm{p}<0.05)$, but the plasma corticosterone response was not affected. In the in vitro study a high concentration of ANP $(1 \mu \mathrm{M})$ reduced basal corticosterone secretion from the isolated rat adrenal gland $(\mathrm{p}<0.05)$, but the response to ACTH $(10 \mathrm{ng} / \mathrm{ml})$ and dibutyryl cyclic AMP $(0.5 \mathrm{mM}, 5.0 \mathrm{mM})$ was not affected. Our data suggest that ANP inhibits hemorrhage-induced ACTH secretion from the anterior pituitary but inhibits corticosterone secretion from the adrenal gland very weakly.
\end{abstract}

The presence of specific granules has been described in the mammalian heart atria, but their function has been unclear (Jamieson and Palade, 1964). Their number changes during sodium loading or depletion (de Bold, 1979). In 1981 de Bold et al. (1981) reported that crude extracts of rat atria injected intravenously produced a rapid and prominent, but transient, diuresis and natriuresis in anesthetized rats, and blood pressure was simultaneously decreased. Garcia et al. (1982) showed that natriuretic activity was closely related to the specific

Received January 21, 1986 granules of atria. Several groups of investigators independently purified and characterized novel peptides from rat atrial extracts (Flynn et al., 1983; Atlas et al., 1984; Currie et al., 1984; Misono et al., 1984; Napier et al., 1984a; Seidah et al., 1984). Kangawa and Matsuo (1984) sucessfully purified a human atrial natriuretic factor, determined its amino acid sequences, and named the peptide alpha-human atrial natriuretic polypeptide ( $\alpha$-hANP). These peptides caused prominent diuresis, natriuresis and vasodilation (Tang et al., 1984; Seymour et al., 1985). Recently, studies have shown that the synthetic atrial na- 
triuretic polypeptide (ANP) inhibited glucocorticoid and mineralocorticoid secretions from the in vitro adrenal cortex (Chartier et al., 1984; De Léan et al., 1984a ; Goodfriend et al., 1984; Kudo and Baird, 1984), but the mechanism of ANP action on the adrenal corticosteroids is unknown.

To investigate the effect of synthetic $\alpha$ hANP on the hypothalamo-pituitary-adrenal axis, we examined changes in ACTH and corticosterone concentrations in hemorrhage stress after $\alpha$-hANP administration. An in vitro study was also performed using isolated rat adrenal blocks.

\section{Materials and Methods}

\section{Cannula implantation}

Twenty male Wistar rats (weighing 250-280 g) were anesthetized with sodium pentobarbital ( $45 \mathrm{mg}$ per $\mathrm{kg}$ body weight, i. p.), and a silicon cannula $\left(0.5 \mathrm{~mm}\right.$ ID, $0.9 \mathrm{~mm}$ OD, Silastic ${ }^{\circledR}$ medical grade tubing, Dow Corning Corp., Michigan, U.S.A.) was inserted into the right jugular vein. The rats were caged individually and received food and water ad libitum. The details of this method were reported by Harms and Ojeda (1974). The day after cannula insertion, experiments were carried out in a quiet, comfortable room $(0900-1200 \mathrm{~h})$. One to $2 \mathrm{~h}$ prior to the experiment, a PE50 polyethylene tubing (Intramedic ${ }^{\circledR}$, Clay Adams, New Jersey, U.S. A.) was connected to the cannula for blood collection. The collecting tubing and cannula were filled with saline containing heparin sodium $(500 \mathrm{U} /$ $\mathrm{ml}$ ), and the end of the tubing was dangled from the cage. The rat was thus able to move freely.

Experiment-I-Effect on hemorrhage-induced response

Four of twenty rats was rejected for obstruction of the cannula. Sixteen rats were randomly divided into three groups. After $2 \mathrm{ml}$ of blood was withdrawn from the cannula with a heparinized syringe, $0.5 \mathrm{ml}$ of saline or synthetic $\alpha$ hANP ( $3 \mu \mathrm{g}$ or $10 \mu \mathrm{g}$ per $\mathrm{kg}$ body weight) was injected intravenously via cannula. Ten and 30 min after injection, $0.5 \mathrm{ml}$ of blood was collected and replaced immediately with the same amount of saline. ACTH and corticosterone were measured from the blood samples.

\section{Experiment II-In vitro study}

Twenty rats weighing $350-400 \mathrm{~g}$ were decapitated. The bilateral adrenal glands were immediately collected. Each adrenal gland was cut into quarters and two pieces were placed into a polyethylene tube, and were incubated in $1 \mathrm{ml}$ of Krebs-Ringer bicarbonate buffer ( $\mathrm{pH}$ 7.4) containing glucose $(0.2 \%)$, bovine serum albumin $(0.25 \%)$, bacitracin $100 \mu \mathrm{g} / \mathrm{ml})$ and ascorbic acid $(1 \mathrm{mM})$. All tubes were placed in a water bath $\left(37^{\circ} \mathrm{C}\right)$ and gently shaken (90 cycles per min) in $\begin{array}{lllll}\text { a } 95 \% & \mathrm{O}_{2}-5 \% & \mathrm{CO}_{2} & \text { atmosphere. } \mathrm{A} \text { series of }\end{array}$ two incubations was performed at $30-\mathrm{min}$ intervals after preincubations. The medium was changed with each incubation, and test substances were added to the medium in the second incubation. The fluid was assayed for corticosterone concentration. Two separate experiments were carried out (1) The effect of synthetic $\alpha$-hANP $\left(10^{-6}, 10^{-7}, 10^{-8} \mathrm{M}\right)$ on the ACTH $(10 \mathrm{ng} / \mathrm{ml})$ induced corticosterone secretion and (2) The effect of $\alpha$-hANP $\left(10^{-7} \mathrm{M}\right)$ on the dibutyryl cyclic-AMP $(0.5,5.0 \mathrm{mM})$-induced corticosterone secretion. The net rate of corticosterone secretion into the medium was indicated by a ratio of the second to the first incubation.

\section{Hormone assay}

Blood was collected into chilled plastic tubes and centrifuged $(1,200 \times \mathrm{g})$ at $4^{\circ} \mathrm{C}$, and plasma samples were stored at $-20^{\circ} \mathrm{C}$ until assay. The plasma ACTH concentration was measured with commercially available radioimmunoassay kits (CEA-IRE-Sorin, France). The plasma corticosterone concentration was also measured with commercially available cortisol radioimmunoassay kits (Daiichi Radioisotope Labs. Ltd., Tokyo). The availability of the kit for corticosterone assay has been described (Hattori et al., 1986). Briefly, synthetic corticosterone was serially diluted with hormone free rat plasma to produce the standard curve. We used $50 \mu \mathrm{l}$ of samples for this assay. The cross reactivity of this antiserum was $7.2 \%$ with corticosterone, $3.5 \%$ to 11-deoxy cortisol and less than $0.5 \%$ with other related hormones (Nakane et al., 1980). As cortisol and 11-deoxy cortisol are thought to be negligible in the rat (Bush, 1951; Ward and Birmingham, 1960), values derived by this method were ascribed mostly to a true corticosterone 
level. The correlation coefficient value obtained by the fluorescent method was $\mathrm{r}=0.8554$ ( $\mathrm{p}<$ 0.01 ). The corticosterone concentration in the incubation medium was assayed by the fluorescent method (Guillemin et al., 1959).

Synthetic $\alpha$-hANP was purchased from the Peptide Institute (Osaka).

\section{Statistical analysis}

Values are presented as means \pm SEM. The differences between the values were estimated by using Student's $t$-test.

\section{Results}

Effect on hemorrhage-induced hormone response

Plasma ACTH concentration continued to increase after hemorrhage, and rose to a ten-fold higher value than the basal level of the control group (Fig. 1a). ANP, however, attenuated the ACTH increase induced by hemorrhage (Fig. 1a). Plasma corticosterone responded to hemorrhage stress in all three groups $(\mathrm{p}<0.05, \mathrm{p}<0.01)$. The increase seemed to be slightly greater in the control group, but there was no statistically significant difference among three groups (Fig. 1b).

Fig. 1a

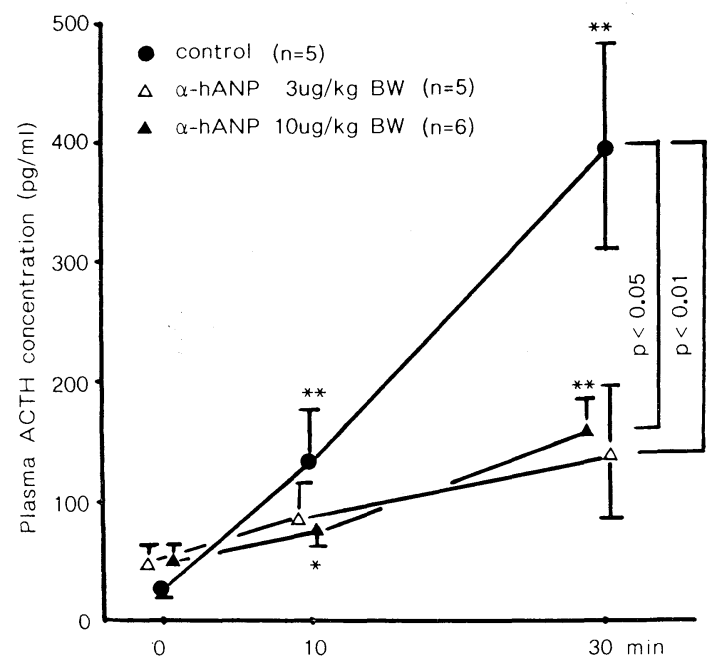

Fig. 1b

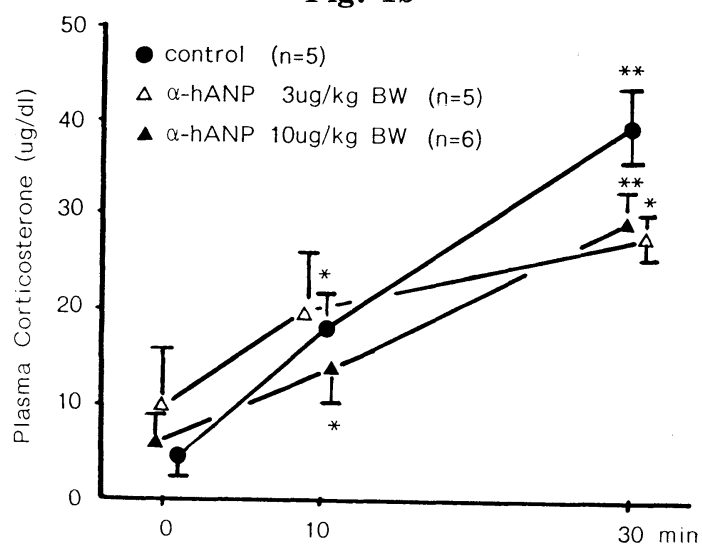

Fig. 1. ACTH (a) and corticosterone (b) response to hemorrhage in rats treated with ANP. Results are expressed as mean \pm SEM. ${ }^{*} \mathrm{p}<0.05,{ }^{*} \mathrm{p}<0.01$ vs 0 time.

\section{Effect on corticosterone secretion in vitro}

A high concentration of ANP $\left(10^{-6} \mathrm{M}\right)$ decreased basal corticosterone secretion, whereas ACTH-induced secretion was not affected (Fig. 2a). ANP had no effect on the cyclic AMP-induced corticosterone secretion (Fig. 2b).

Fig. 2a
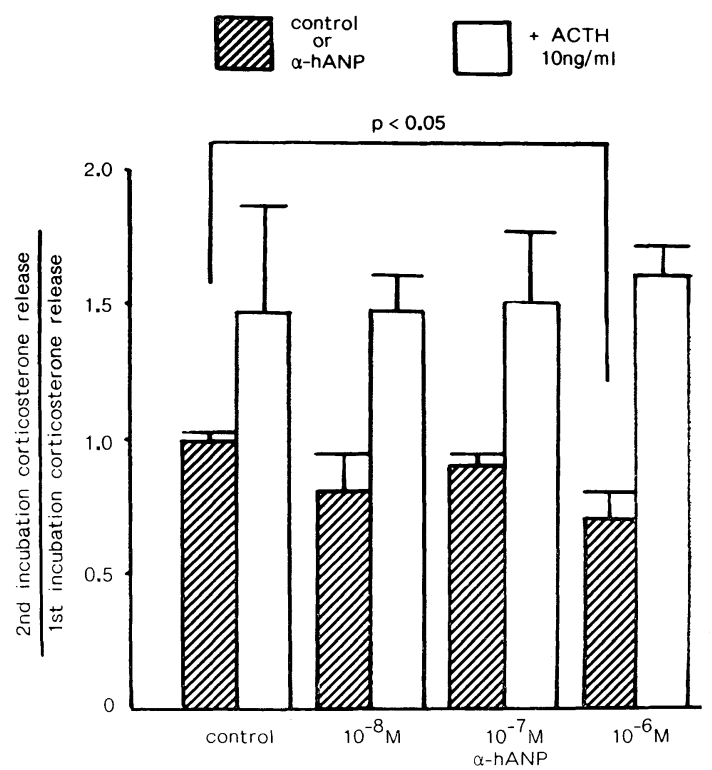
Fig. 2b

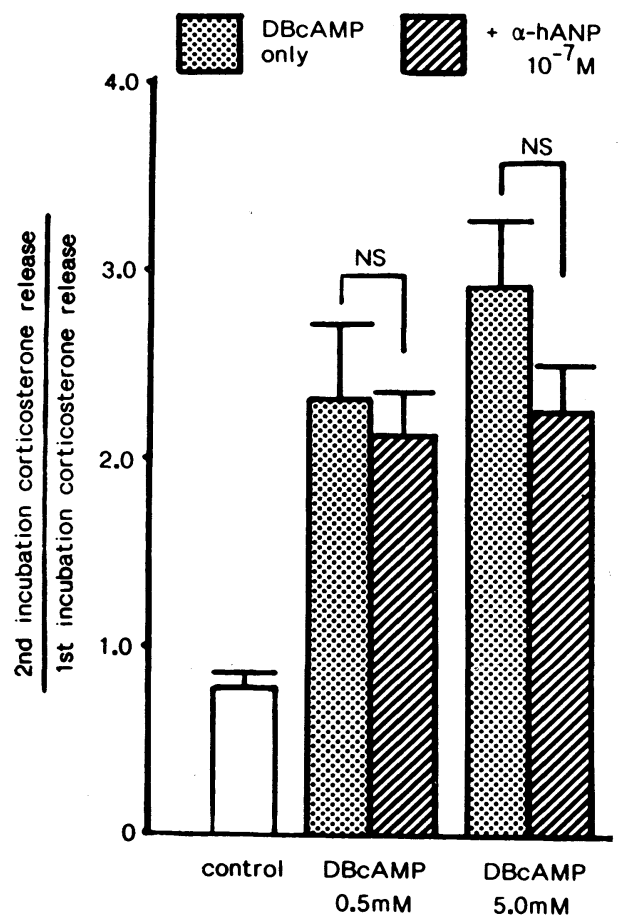

Fig. 2. Effect of ANP on corticosterone release from the isolated rat adrenal gland induced by ACTH (10 ng/ml) (a) and dibutyryl cyclic AMP (0.5 and $5.0 \mathrm{mM})(\mathrm{b})$. The number in each group is six $(n=6)$. Results are expressed as mean \pm SEM. The net rate of corticosterone secretion into the medium was indicated by a ratio of the second to the first incubation.

\section{Discussion}

It is interesting that the hemorrhageinduced ACTH secretion was inhibited by ANP. A similar effect was reported in vasopressin secretion stimulated by hemorrhage (Samson, 1985). Plotsky et al. (1985) reported that corticotropin-releasing factor (CRF) and vasopressin secretions from the median eminence were involved in hemorrhage-induced ACTH secretion. The inhibition of adenylate cyclase activity by synthetic ANF in the anterior and posterior pituitary was also demonstrated (Anand-
Srivastava et al. 1985b). Thus, ANP may inhibit ACTH secretion from the anterior pituitary via inhibition of adenylate cyclase activity in the pituitary or inhibition of CRF or vasopressin release from the median eminence.

The mechanism of ANP action on steroidogenesis is still unknown. Anand-Srivastava et al. (1985a, 1985b) demonstrated adenylate cyclase inhibition by synthetic ANP in various endocrine organs. Other investigators (Hirata et al., 1984; Napier et al., 1984; De Léan et al., 1985a., Hori et al., 1985; Ogura et al., 1985; Shiffrin et al., 1985) reported the presence of a specific ANP receptor in various organs. Goodfriend et al. (1984) postulated that ANP inhibited the early pathway of steroidogenesis in the adrenal cortex. Some reports have showed that ANP has an inhibitory effect on the basal aldosterone level and on the secretion from rat adrenal glomerulosa cells stimulated by ACTH or angiotensin II (Chartier et al., 1984 ; Kudo and Baird, 1984). These results are not consistent with a study using crude atrial extracts (Atarashi et al., 1984). Atrial extracts and synthetic ANP were reported to have no effect on the corticosterone release from rat zona fasciculata cells (Chartier et al., 1984; Kudo and Baird, 1984). In studies using bovine zona fasciculata cells however, the results were different (De Léan et al., 1984b; Goodfriend et al., 1984; Kudo and Baird, 1984). De Léan et al. (1984b) demonstrated a specific receptormediated inhibition of synthetic ANP in cortisol secretion from bovine zona fasciculata cells. On the other hand, Kudo and Baird (1984) reported no effect on hormone secretion from rat and bovine fasciculata cells. In the present study, synthetic ANP showed only a weak inhibitory effect on basal corticosterone secretion in in vitro experiments. In addition, hormone secretion stimulated by ACTH or dibutyryl cyclic AMP was not affected by ANP. The dose 
of ACTH which we used in the in vitro study was a submaximal one. Our data cannot rule out the possibility that the release of corticosterone induced by a lower dose of ACTH might be inhibited by ANP.

It has been known that hemorrhage is one of the strong stimuli to corticosteroid secretion. The release of ACTH is thought to be responsible for the adrenocortical response to hemorrhage. In the present study, however, there was no statistically significant difference in the corticosterone response to hemorrhage stress between control and ANP-injected groups although the ACTH response was strongly suppressed by ANP. We cannot explain this discrepancy. A significant difference might be found if blood collection was continued after $30 \mathrm{~min}$ of ANP administration. ACTH-independent mechanisms of the corticoid secretion may be involved in hemorrhage-induced response. Wood et al. (1982a) demonstrated the dissociation of ACTH and corticosteroid response to hemorrhage, and they presumed that this could be ascribed to an increase in the adrenal sensitivity to ACTH during hemorrhage (Wood et al., 1982b). Direct neural control of the adrenocortical response is also postulated (Gann, 1979). In addition, it has been reported that there may be another ACTH-independent system in corticosteroid secretion (Graybeal et al., 1985). It is possible that the ACTH-independent mechanism of corticosteroid secretion is modulated by ANP.

\section{Acknowledgements}

We thank Miss Reiko Akiyama and Mr. Makoto Aoi for technical assistance.

\section{References}

Anand-Srivastava, M. B., J. Genest and M. Cantin (1985a). Inhibitory effect of atrial natriuretic factor on adenylate cyclase activity in adrenal cortical membranes. FEBS Lett. 181, 199-202.

Anand-Srivastava, M. B., M. Cantin and J. Genest (1985b). Inhibition of pituitary adenylate cyclase by atrial natriuretic factor. Life Sci. 36, 1873-1879.

Atlas, S. A., H. D. Kleinert, M. J. Camargo, A. Januszewicz, J. E. Sealey, J. H. Laragh, J. W. Schilling, J. A. Lewicki, L. K. Johnson and T. Maack (1984). Purification, sequencing and synthesis of natriuretic and vasoactive rat atrial peptide. Nature 309, 717-719.

Atarashi, K., P. J. Mulrow, R. Franco-Saenz, R. Snajdar and J. Rapp (1984). Inhibition of aldosterone production by an atrial extract. Science 224, 992-994.

Bush, I. E. (1951). Paper-chromatographic study of the secretion of the adrenal cortex in various mammalian species. J. Physiol. (London) 115, 12P-13P.

Chartier, L., E. Shiffrin, G. Thibault and R. Garcia (1984). Atrial natriuretic factor inhibits the stimulation of aldosterone secretion by angiotensin II, ACTH and potassium in vitro and angiotensin II-induced steroidogenesis in vivo. Endocrinology 115, 2026-2028.

Currie, M. G., D. M. Geller, B. R. Cole, N. R. Siegel, K. F. Fok, S. P. Adams, S. R. Eubanks, G. R. Galluppi and P. Needleman (1984). Purification and sequence analysis of bioactive atrial peptides (Atriopeptins). Science 223, 6769.

de Bold, A. J. (1979). Heart atria granularity effects of changes in water-electrolyte balance. Proc. Soc. Exp. Biol. Med. 161, 508-511.

de Bold, A. J., H. B. Borenstein, A. T. Veress and H. Sonnenberg (1981). A rapid and potent natriuretic response to intravenous injection of atrial myocardial extract in rats. Life Sci. 28, 89-94.

De Léan, A., K. Racz, J. Gutkowska, T-T. Nguyen, M. Cantin and J. Genest (1984a). Specific receptor-mediated inhibition by synthetic atrial natriuretic factor of hormone-stimulated steroidogenesis in cultured bovine adrenal cells. Endocrinology 115, 1636-1638.

De Léan, A., J. Gutkowska, N. McNicoll, P. W. Schiller, M. Cantin and J. Genest (1984b). Characterization of specific receptors for atrial natriuretic factor in bovine adrenal zona glomerulosa. Life Sci. 35, 2311-2318.

Flynn, T. G., M. L. de Bold and A. J. de Bold (1983). The amino acid sequence of an atrial peptide with potent diuretic and natriuretic 
properties. Biochem. Biophys, Res. Commun. 117, 859-865.

Gann, D. S. (1979). Cortisol secretion after hemorrhage: multiple mechanisms. Nephron 23, 119-124.

Garcia, R., M. Cantin, G. Thibault, H. Ong and J. Genest (1982). Relationship of specific granules to the natriuretic and diuretic activity of rat atria. Experientia 38, 1071-1073.

Goodfriend, T. L., M. E. Elliott and S. A. Atlas (1984). Actions of synthetic atrial natriuretic factor on bovine adrenal glomerulosa. Life Sci. 35, 1675-1682.

Graybeal, M. L., V. S. Fang and R. L. Landau (1985). Enhancement of adrenal cortisol secretion after intravenous high dose dexamethasone. J. Clin. Endocrinol. Metab. 61, 607-611.

Guillemin R., G. W. Clayton, H. S. Lipscomb and J. D. Smith (1959). Fluorometric measurement of rat plasma and adrenal corticosterone concentration. A note on technical details. J. Lab. Clin. Med. 53, 830-832.

Harms, P. G. and S. R. Ojeda (1974). A rapid and simple procedure for chronic cannulation of the rat jugular vein. J. Appl. Physiol. 36, 391-392.

Hattori, T., K. Hashimoto and Z. Ota (1986). Adrenocorticotropin responses to corticotropinreleasing factor and vasopressin in spontaneously hypertensive rats. Hypertension 8, 386390.

Hirata, Y., M. Tomita, H. Yoshimi and M. Ikeda (1984). Specific receptors for atrial natriuretic factor (ANF) in cultural vascular smooth muscle cells of rat aorta. Biochem. Biophys. Res. Commun. 125, 562-568.

Hori, R., K. Inui, H. Saito, Y. Matsukawa, K. Okumura, K. Nakao, N. Morii and H. Imura (1985). Specific receptors for atrial natriuretic polypeptide on basolateral membranes isolated from rat renal cortex. Biochem. Biophys. Res. Commun. 129, 773-779.

Jamieson, J. D. and G. E. Palade (1964). Specific granules in atrial muscle cells. J. Cell Biol. $23,151-172$.

Kangawa K. and H. Matsuo (1984). Purification and complete amino acid sequence of $\alpha$ human atrial natriuretic polypeptide ( $\alpha$-hANP). Biochem. Biophys. Res. Commun. 118, 131-139.

Kudo, T. and A. Baird (1984). Inhibition of aldosterone production in the adrenal glomerulosa by atrial natriuretic factor. Nature 312 , 756-757.

Misono, K. S., H. Fukumi, R. T. Grammer and
T. Inagami (1984). Rat atrial natriuretic factor: complete amino acid sequence and disulfide linkage essential for biological activity. Biochem. Biophys. Res. Commun. 119, 524-529.

Nakane, T., A. Kuwae, M. Watanabe and N. Kanie (1980). Fundamental study and clinical application of SPAC cortisol kit. (in Japanese) Horumon To Rinsho 28, 193-197.

Napier, M. A., R. S. Dewey, G. Albers-Schönberg, C. D. Bennett, J. A. Rodkey, E. A. Marsh, M. Whinnery, A. A. Seymour and E. H. Blaine (1984a). Isolation and sequence determination of peptide components of atrial natriuretic factor. Biochem. Biophys. Res. Commun. 120, 981-988.

Napier, M. A., R. L. Vandlen, G. Albers-Schönberg, R. F. Nutt, S. Brady, T. Lyle, R. Winquist, E. P. Faison, L. A. Heinel and E. H. Blaine (1984b). Specific membrane receptors for atrial natriuretic factor in renal and vascular tissues. Proc. Natl. Acad. Sci. USA. 81, 5946-5950.

Ogura, T., T. Mitsui, N. Ogawa and Z. Ota (1985). Specific receptor binding of atrial natriuretic peptide to rat renal cortex. Res. Commun. Chem. Path. Pharm. 49, 353-360.

Plotsky, P. M., T. O. Bruhn and W. Vale (1985). Evidence for multifactor regulation of the adrenocorticotropin secretory response to hemodynamic stimuli. Endocrinology 116, 633639.

Samson, W. K. (1985). Atrial natriuretic factor inhibits dehydration and hemorrhage-induced vasopressin release. Neuroendocrinology 40, 277-279.

Seidah, N. G., C. Lazure, M. Chrétien, G. Thibault, R. Garcia, M. Cantin, J. Genest, R. F. Nutt, S. F. Brady, T. A. Lyle, W. J. Paleveda, C. D. Colton, T. M. Ciccarone and D. F. Veber (1984). Amino acid sequence of homologous rat atrial peptides: Natriuretic activity of native and synthetic forms. Proc. Natl. Acad. Sci. USA 81, 2640-2644.

Seymour, A. A., E. H. Blaine, E. K. Mazack, S. G. Smith, I. I. Stabilito, A. B. Haley, M. A. Napier, M. A. Whinnery and R. F. Nutt (1985). Renal and systemic effects of synthetic atrial natriuretic factor. Life Sci. 36, 33-44.

Shiffrin, E. L., L. Chartier, G. Thibault, J. StLouis, M. Cantin and J. Genest (1985). Vascular and adrenal receptors for atrial natriuretic factor in the rat. Circ. Res. 56, 801807. 
Tang, J., R. J. Webber, D. Chang, J. K. Chang, J. Kiang and E. T. Wei (1984). Depressor and natriuretic activity of several atrial peptides. Regul. Peptides 9, 53-59.

Ward, P. J. and M. K. Birmingham (1960). Properties of the ultraviolet-absorbing lipids produced by rat adrenals in vitro. Biochem. $J$. 76, 269-279.

Wood, C. E., J. Shinsako, L. C. Keil, D. J.
Ramsay and M. F. Dallman (1982a). Apparent dissociation of adrenocorticotropin and corticosteroid responses to $15 \mathrm{ml} / \mathrm{kg}$ hemorrhage in conscious dogs. Endocrinology 110, 1416-1421. Wood, C. E., J. Shinsako, L. C. Keil and M. F. Dallman (1982b). Adrenal sensitivity to adrenocorticotropin in normovolemic and hypovolemic conscious dogs. Endocrinology 110, 1422-1429. 